\title{
Michał Kieling, Rola Pisma Świętego i „artes liberales” w kształtowaniu nauk teologicznych i świeckich według Kasjodora, Uniwersytet Adama Mickiewicza, Wydział Teologiczny, Studia i Materiały 141, Poznań 2011, 261 s.
}

W omawianej książce Michał Kieling jako cel badawczy postawił sobie opisanie życia, działalności oraz koncepcji nauki świeckiej i chrześcijańskiej Kasjodora z Vivarium (ok. 485/490 - ok. 580). Szkoda, że przy opisie biogramu Kasjodora we Wstępie (s. 13-21) nie wyjaśnił, dlaczego Kasjodor lojalnie służył tylko ariańskim Ostrogotom (Teodorykowi, Amalasuncie czy Teodathowi), natomiast zupełnie wycofał się ze służby dworskiej w 540 roku po zajęciu Italii przez katolickie oddziały Cesarstwa Bizantyjskiego. Autor pisze, że to wówczas nastąpił w życiu Kasjodora zwrot, który określany jest jako conversio (s. 17). Jeśli utrata władzy nad Italią przez Ostrogotów i utrata polityczno-towarzyskiego pośrednictwa pomiędzy dawnymi rodami rzymskimi a Gotami spowodowały u Kasjodora wstrząs egzystencjalny, to taka conversio nie była raczej motywowana względami religijnymi...

Natomiast fakt, iż Kasjodor - nie będąc ani duchownym, ani żołnierzem - zajmował jednak wysokie stanowisko na dworze Ostrogotów w Rawennie (s. 17) nie powinien dziwić. Dlaczego? Otóżautor wcześniej wspomniał, że pradziadek Kasjodora był dowódcą obrony Sycyli i Brucji przeciwko flocie Wandali dowodzonych przez Genzeryka (428-477), dziadek Kasjodora był trybunem za panowania cesarza Walentyniana III (434-453), a ojciec Kasjodora byłjużuznanym urzędnikiem administracji Ostrogockiej w Italii za panowania króla Teodoryka Wielkiego (493-526), zarządcą Lukanii i Brucji, praefectus praetorium et patricius (s. 14). Kasjodor zatem wcale nie musiał być żołnierzem czy duchownym, aby osiągnąć najwyższe stanowiska administracyjne w państwie Ostrogotów. 
Familia Casiodorii była typową rodziną wyższych urzędników państwowych, doskonale służących każdej władzy, która pozwalała im na najwyższe dochody i tytuły. Rodzinne koneksje i znajomości na dworze Ostrogotów zapewniły Kasjodorowi te same dochody i tytuły, które posiadał wcześniej jego ojciec: consiliarius, quaestor sacrii palatii, consul ordinarius, magister officiorum, praefectus pretorium i wreszcie patricius...

$\mathrm{Na}$ stronach 37-38 autor przytacza za Theodorem Klauserem i Wolfgangiem Bürsgensem hipotezęo podobieństwie pomiędzy Institutiones Kasjodora a 21 statutami szkoły w Nisibis. Być może Kasjodor zetknął się, przebywając w Konstantynopolu, z ideami szkoły w Nisibis, które później wykorzystał w Vivarium. To jednak tylko hipoteza. Przeciwko niej świadczy jeden fakt, wynikający z analizy literackiej: Kasjodor nigdzie nie powołuje się na któregokolwiek z egzegetów i teologów syryjskich, którzy pochodzili czy uczyli w szkole w Nisibis: Efrema Syryjczyka, Ibasa z Edessy, Narsaja z Edessy, Teodora z Mopsuestii,Nestoriusza, Teodoreta z Cyru, Barsaumy czy Babaja Wielkiego, nie ma też w swojej bibliotece ani jednego dzieła teologów syryjskich (s. 51-52).

Kieling (s. 61-62) opisuje zastosowanie sześciu sposobów odczytywania tekstu biblijnego przez Kasjodora (de modi intelligentiae). Mistrz z Kalabrii odwoływał się głównie do autorów łacińskich (Tykoniusza, Augustyna, Eucheriusza z Lyonu, Juniliusza) i tylko do jednego greckiego - Hadriana. Brak powołania się na egzegetów syryjskich świadczy kolejny raz przeciwko hipotezie o wpływie Nisibis na Vivarium. Zastanawia natomiast potężne uprzedzenie Kasjodora do egzegezy Orygenesa: ,według wielu ojców Kościoła jest on heretykiem”; „z Orygenesem należy postępować jak z koprem... (odgotować, wycisnąć, wyrzucić)” (s. 90); „Szukam złota w kupie gnoju" (s. 91). Szkoda, że autor nie zadał sobie pytania badawczego: dlaczego Kasjodor był tak uprzedzony do Orygenesa? Wiemy, że pisarz z Vivarium był w Konstantynopolu w latach 550-554, a cesarz Justynian I Wielki zwołał sobór konstantynopolitański II właśnie w 553 roku, gdzie pod wpływem cesarskich nacisków politycznych potępiono teologów syryjskich (Trzy rozdziały), Orygenesa i papieża Wigiliusza... Być może Kasjodor, będąc świadkiem tych wydarzeń, zasugerował się retoryką teologii politycznej uprawianej przez Justyniana i zależnych od niego orzeczeń soborowych?

Zasady korekty tekstu biblijnego zasadniczo zostały przez Kasjodora wyprowadzone $z$ retoryki. Było to powiązanie klasycznego emendatio z regułami interpretacyjnymi Hieronima (s. 63-66). Zasada retorycznej interpretacji Biblii jest u Kasjodora szczególnie zauważana, kiedy uznaje Augustyna za naczelny autorytet teologiczny w interpretacji Pisma Świętego (s. 73-75), Hieronimowa Vulgata ,jest dla naszego autora tak doskonałym przekładem, że nie potrzeba sięgać do hebrajskiego tekstu oryginalnego" (s. 76), a łacińscy komentatorzy Biblii są uznani za przydatniejszych, ,ponieważ ich dzieła napisane zostały w języku ojczystym" (s. 86). Powyższe opinie Kasjodora, skrupulatnie przytaczane przez autora, świadczą niestety o braku krytycyzmu mistrza z Vivarium wobec przekładów i o słabości egzegezy opartej nie tyle o tekst oryginalny, ile o uznane i wybrane autorytety teologiczne. Kalabryjczyk uprawiał hermeneutykę biblijną według zasad alegorezy łacińskiej (Augustyn i Hieronim), która w dużej mierze korzystała z myśli Orygenesa, ale ideologicznie pomijała milczeniem albo dyskredytowała tego najwybitniejszego alegorystę... Kasjodor proponował retoryczno-symboliczną egzegezę biblijną, od- 
wołującą się do obrazowości i typologii zawartych w łacińskim tłumaczeniu tekstu biblijnego (Vulgata), która nie uwzględnia oryginału hebrajskiego i greckiego. Tekst biblijny był przez Kasjodora wykorzystany do apriorycznej argumentacji, która bazowała na dialektyce i retoryce.

Prezentując relację Pisma Świętego do nauk świeckich (s. 105-134), autor wskazuje na spór pomiędzy filozofią a retoryką. Odnosi się wrażenie, że u pisarzy łacińskich V wieku zwyciężyła opcja retoryczna. Być może na Zachodzie w V wieku Orygenes był tak nieakceptowany, bo pisarz aleksandryjski ustawił kształcenie w oparciu o filozofię? Michał Kieling podaje, że w pedagogicznej myśli średniowiecza wyróżnia się dwie teorie dotyczące sztuk wyzwolonych: patrystyczną i świecko-szkolną. Jak słusznie podkreśla Kieling (s. 125), sformułowany przez Kalabryjczyka kanon nauk, omówienie siedmiu artes liberales, odniesienie trivium do quadrivium przyczyniły się do pogłębienia relacji pomiędzy naukami chrześcijańskimi a świeckimi. Ideą naczelną tego programu było założenie, że nauki świeckie posiadają służebny charakter wobec teologii, a ich celem jest teologiczna propedeutyka (s. 133).

Proces kształcenia został porównany przez Kasjodora do etapów leczenia. Gramatyka zostaje przez niego uznana za najważniejszą ze sztuk, gdyż określa ona właściwe metrum (opinia powtarzana za Augustynem, s. 136), konieczne do studiowania Biblii i łaciny (s. 138). Jak słusznie odnotowuje Kieling, celem tak pojmowanej nauki świeckiej i chrześcijańskiej była dla Kasjodora aeterna salus (s. 163). Przez stopniowe wznoszenie się $\mathrm{w}$ wiedzy według ordo disciplinarum uczeń przechodził z rzeczywistości ziemskich („wznosił się”) do rzeczywistości niebiańskich (s. 164), a przez illuminatio dochodził do kontemplacji tajem- nic i poznania Jezusa Chrystusa (s. 165). Kształtowanie wiary w oparciu o poznanie rozumowe i rozwijanie pragnienia nieba i zbawienia dopełniały się według Kasjodora na drodze stopniowego wstępowania do:Pisma, tajemnic, Boga. Autor słusznie zaznacza, że obok idei biblijnych widać w schemacie rozumowania, zastosowanym przez mistrza z Vivarium neoplatoński model pojmowania świata (s. 167).

Podając opis zastosowania nauk świeckich na przykładzie dzieła Kasjodora Expositio Psalmorum, Michał Kieling podtrzymuje opinię Reinharda Schliebena, że Expositio Psalmorum stanowi pierwszy systematyczny łaciński komentarz do Psalmów. Wzbudził on jednak małe zainteresowanie w historii egzegezy właśnie ze względu na jego podręcznikowy charakter oraz retoryczną konstrukcję (s. 167). W opinii Kielinga Kasjodor pragnął podać czytelnikowi tekst pozbawiony błędów gramatycznych i ortograficznych, gdyż każda łacińska sylaba i litera tekstu Vulgaty posiadały dla niego swój sens. Dlatego najbardziej istotne miejsce w Expositio Psalmorum zajmuje analiza retoryczna owych znaczeń łacińskich. Kasjodor dokonał swoistej retoryzacji Księgi Psalmów, tekst jego komentarza zdaje się przeładowany czy ozdobny. W tej metodzie retoryzacji Biblii mistrzem dla Kasjodora był oczywiście Augustyn z Hippony. Dlatego nie dziwi, że alegoria według Kasjodora miała za zadanie ukryć właściwy sens tekstu natchnionego przed bezbożnymi, a ujawnić go przed wierzącymi, gdyż figury obok funkcji estetycznych posiadały funkcję ukrywania myśli, które przekazuje podmiot retoryczny. Zwieńczeniem tego typu myślenia retorycznego w odniesieniu do interpretacji Psalmów stała się dla Kasjodora jego egzegeza numerologiczna (s. 195-216). 
Michał Kieling dobrze przedstawił role Pisma Świętego i cyklu sztuk wyzwolonych w kształtowaniu nauk teologicznych i świeckich w ujęciu Kasjodora z Vivarium. Autor pracy wykazał, że zdaniem Kalabryjczyka wszelka wiedza i nauka posiada jedno wspólne źródło, którym jest Pismo Święte. Według Kasjodora w Biblii są bowiem zawarte nasiona artes liberales, które zostały przejęte przez autorów greckich, a następnie łacińskich. Zakładając ich biblijną legitymizację, sztuki wyzwolone byłyby zintegrowane z teologia i nie stałyby w jakiejkolwiek opozycji wobec nauk chrześcijańskich, ale pełniłyby rolę pożytecznego narzędzia i środka propedeutyki teologii.Jak trafnie twierdzi Kieling, Kasjodor chciał przełamać panujące w Kościele zachodnim VI wieku stereotypy nieufności wobec stosowania artes liberales $\mathrm{w}$ teologii i zaangażować środowisko monastyczne na rzecz nauki i kultury. Autor opracowania wykazał, że w dziełach Kasjodora dokonała się synteza nauczania teologicznego i świeckiego.Jej podstawowa teza głosi, że racjonalność nauki teologicznej powinna być wspierana przez sztuki wyzwolone jako narzędzia pomocnicze teologii. Wiedza świecka połączona z wiedzą teologiczną mają prowadzić wierzącego do zbawienia w Bogu.

Recenzowana książka Michała Kielinga stanowi cenny wkład w rozwój polskiej patrologii. Autor swobodnie porusza się w źródłach i opracowaniach dotyczących mistrza z Vivarium. Dysertacja jest napisana językiem komunikatywnym, a książka jest wydana starannie i zredagowana w sposób rzeczowy. Jest to praca dojrzała, ukazująca możliwości badawcze jej autora. Wspomniane nieliczne zastrzeżenia nie podważają zasadniczych wartości naukowych omawianej pracy. Autor wykazał się opanowaniem warsztatu badawczego zarówno na płaszczyźnie formalnej, jak i merytorycznej.

Dariusz Kasprzak OFMCap 